\title{
Threatened fishes of the world: Achondrostoma occidentale Robalo, Almada, Sousa-Santos, Moreira \& Doadrio 2005 (Cyprinidae)
}

\author{
Joana I. Robalo • Carla Sousa-Santos • \\ Ignacio Doadrio • Vítor C. Almada
}

Received: 27 September 2007 / Accepted: 26 March 2008

(C) Springer Science + Business Media B.V. 2008

Common name: Ruivaco do Oeste (Portuguese); western ruivaco. Conservation status: According to the IUCN criteria B1ab (i, ii, iii) + 2ab (i, ii, iii) this species must be considered Critically Endangered (Robalo et al. 2005). Identification: This small cyprinid (about $100 \mathrm{~mm}$ TL) differs from the other members of its genus (A. arcasii and A. oligolepis) by the following combination of characters: $40-43$ canaliculate scales on the lateral line, six to seven scales above the lateral line, two to three scales below the lateral line, axillary pelvic scale shorter than or equal to the insertion of the pelvic fin and a very thick coronoid process of the dentary (Robalo et al. 2005). Distribution: It occurs in three small coastal streams (Sizandro, Safarujo and Alcabrichel rivers) in west central Portugal (apparently extinct in the river Safarujo). Abundance: The two surviving populations are extremely small. The species is now restricted to small isolated pockets located upstream of the major sources of pollution in the rivers Alcabrichel and Sizandro. Habitat and ecology: This fish lives in small coastal Mediterranean type streams surviving

J. I. Robalo $(\bowtie) \cdot$ C. Sousa-Santos $\cdot$ V. C. Almada

Unidade de Investigação em Eco-Etologia,

Instituto Superior de Psicologia Aplicada,

34, Lisboa 1149-041, Portugal

e-mail: jrobalo@ispa.pt

I. Doadrio

Museo Nacional de Ciencias Naturales,

José Gutiérrez Abascal 2, Madrid 28006, Spain

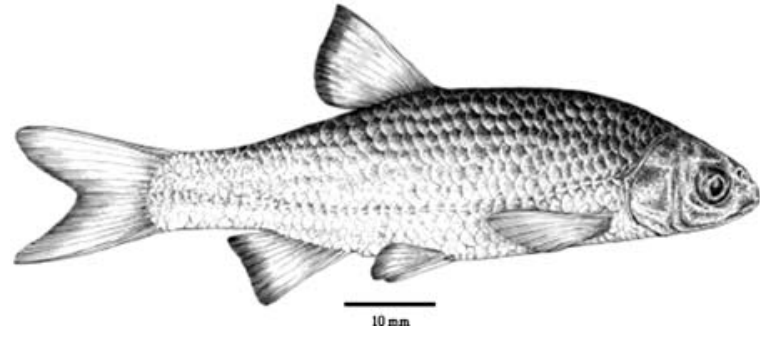

the summer in small pools under the shade of vegetation. Reproduction: A. occidentale breeds in late April and May, forming spawning aggregations and releasing adhesive eggs over stones and vegetation (Pereira 2007). Threats: Sewage from pig farms, distilleries, agricultural and urban pollution. Conservation: No conservation measures are known at this date. Conservation recommendations: Ex situ reproduction seems very urgent to preserve fish until the rivers are restored. River restoration measures should be seriously considered. The genetic variability of the two surviving populations should be evaluated.

\section{References}

Pereira AM (2007) Estudo comparativo do comportamento reprodutor em espécies do género Achondrostoma (Pisces, Cyprinidae). MS thesis, ISPA, Lisboa

Robalo JI, Almada VC, Sousa Santos C et al (2005) New species of the genus Chondrostoma Agassiz, 1832 (Actynopterigii, Cyprinidae) from western Portugal. Graellsia 61(1):19-29 